\title{
PERANAN PERPUSTAKAAN DAN MUSEUM TEMBAKAU DALAM PELESTARIAN KEBUDAYAAN KOTA JEMBER
}

\author{
Karina Okta Bella \\ karinaabellaa@gmail.com \\ Universitas Negeri Malang
}

\begin{abstract}
ABSTRAK: Tujuan penulisan artikel ini yaitu memaparkan (1) faktor yang menjadi alasan dilakukan pelestarian tembakau di Kota Jember, (2) pentingnya tembakau bagi masyarakat Kota Jember, (3) peran perpustakaan dan museum tembakau bagi masyarakat Kota Jember serta kendala yang dihadapi dalam pelaksanaannya, dan (4) upaya yang telah dilakukan kaitannya dengan budaya tembakau di Kota Jember dan upaya pengembangan perpustakaan dan museum tembakau kedepannya. Hasil analisis studi kasus yang telah dibahas diketahui bahwa potensi sumber daya alam (SDA) dan sumber daya manusia (SDM) sangat mendukung didalam pengembangan tanaman tembakau dan kebudayaanya. Namun, terdapat beberapa dampak didalamnya misalkan meningkatnya pendapatan pemerintah daerah diringi dengan peningkatan konsumsi rokok di Kota Jember. Selain itu, juga terdapat peran perpustakaan dan museum tembakau dimana budaya tembakau dapat terjaga serta masyarakat memiliki wadah agar slalu mengerti nilai penting adanya budaya tembakau yang menjadi ciri khas dari Kota Jember.
\end{abstract}

Kata kunci: Perpustakaan dan Museum, Pelestarian, Kebudayaan

\begin{abstract}
The purpose of writing this article that describes (1) the factors is the reason to do the preservation of tobacco in Jember City, (2) the importance of tobacco for the city of Jember, (3) the role of libraries and museums tobacco for the city of Jember and obstacles encountered in the implementation and (4) the efforts that have been made do with the tobacco culture in the city of Jember and development efforts in the future of libraries and museums tobacco. The case study analysis that has been discussed is known that the potential of natural resources (SDA) and human resources (HR) very supportive in the development of tobacco plants and their culture. However, there are some impacts suppose therein lacks local government revenues increased with an increase in cigarette consumption in the city of Jember. In addition, there is also the role of libraries and museums tobacco where the tobacco culture can be maintained and the public has a container in order to understand the significance of their pobud tobacco culture that is characteristic of the city of Jember.
\end{abstract}

Keywords: Library and Museum, Wildlife, Culture 
Globalisasi budaya yang begitu pesat harus diantisipasi dengan memperkuat identitas kebudayaan. Pelestarian kebudayaan perlu dilakukan agar ciri khas atau ikon kebudayaan terjaga identitasnya dan tetap lestari salah satunya tembakau yang ada di kota Jember. Tembakau yang merupakan warisan budaya masa lalu tentu memuat catatan berharga di masa itu yang memiliki keterkaitan erat dengan masyarakat sekarang khususnya kota Jember. Tembakau adalah ciri khas Jember, yang menjadi penanda bahwa kota tersebut adalah salah satu kota penghasil tembakau terbesar di Indonesia dan terlihat dari dalam logo daerah Jember sendiri terdapat gambar daun tembakau yang menunjukan jika daun tembakau tersebut merupakan bagian penting yang dimiliki oleh kota tersebut. Penekanan kepada masyarakat mengenai pentingnya dan mempelajari pengetahuan nilai-nilai yang termuat di dalamnya akan menumbuhkan pemahaman bahwa kekayaan yang tak ternilai harganya tersebut merupakan khasanah kebudayaan bangsa yang harus dilestarikan.

Terkait dengan hal itu, perpustakaan sebagai tempat untuk menyimpan dan menyebarkan ilmu pengetahuan memainkan peranan yang signifikan. Penyimpanan khasanah budaya bangsa atau masyarakat tempat perpustakaan berada serta peningkatan nilai serta apresiasi budaya dari masyarakat sekitar perpustakaan melalui penyediaan bahan bacaan, bahan rekam, dan peninggalan sejarah yang merupakan fungsi kultural perpustakaan dalam kebudayaan. Berdasarkan penjelasan yang dikemukakan oleh Prof. Dr. Sulistyo-Basuki dalam Pengantar Ilmu Perpustakaan (1991) tersebut, perluasan fungsi kultural perpustakaan nantinya harus mengarah pada upaya pelestarian nilai-nilai kebudayaan.

Fungsi perpustakaan yaitu melestarikan khasanah budaya bangsa, oleh sebab itu tembakau tersebut harus dilestarikan mengingat nilainya yang sangat tinggi serta memiliki rekaman hasil budaya suatu bangsa yang merupakan catatan atau rekaman hasil pemikiran masyarakat. Perpustakaan yang memiliki peran dalam pelestarian kebudayaan salah satunya Perpustakaan dan Museum Tembakau di kota Jember, dimana Perpustakaan dan Museum Tembakau tersebut memuat berbagai sejarah dan nilai-nilai keseluruhan tentang tembakau.

Dengan alasan itulah penulis tertarik untuk melihat bagaimana pelestarian ciri 
khas atau bahan pustaka tembakau dengan memfokuskan pada Perpustakaan dan Museum Tembakau di Jember. Maka dari itu Penulis ingin mengetahui penerapan pelestarian tembakau di Perpustakaan dan Museum Tembakau Kota Jember.

Tujuan penulisan artikel ini yaitu memaparkan (1) faktor yang menjadi alasan dilakukan pelestarian tembakau di Kota Jember, (2) pentingnya tembakau bagi masyarakat Kota Jember, (3) peran perpustakaan dan museum tembakau bagi masyarakat Kota Jember serta kendala yang dihadapi dalam pelaksanaannya, dan (4) upaya yang telah dilakukan kaitannya dengan budaya tembakau di Kota Jember dan upaya pengembangan perpustakaan dan museum tembakau kedepannya.

\section{LANDASAN TEORI}

\section{Perpustakaan}

Perkembangan dunia perpustakaan dilihat dari segi koleksi daya dan dokumen yang disimpan, diawali dari perpustakaan tradisional yang hanya terdiri dari kumpulan koleksi buku tanpa katalog, kemudian muncul pepustakaan semi modern yang menggunakan katalog (index). Perkembangan yang mutahir adalah dengan munculnya perpustakaan digital (digital library) yang memiliki keunggulan dalam kecepatan pengaksesan karena berorientasi ke data digital dan media jaringan computer (internet). Selain itu, juga munculnya perpustakaan yang bergabung dengan museum guna melestarikan khasanah kebudayaan. Perpustakan diartikan sebagai institusi yang menyediakan koleksi bahan pustaka tertulis, tercetak dan terekam sebagai pusat sumber informasi yang diatur menurut system aturan dan didayagunakan untuk keperluan pendidikan, penelitian serta rekreasi intelektual bagi masyarakat.

Menurut Supriyanto dan Muhsin (2012), perpustakaan memberikan layanan literatur dan bahan referensi yang diperlukan oleh para pengguna. Didalam tata aturan perpustakaan, tujuan diberikannya perpustakaan adalah sebagai berikut:

1. Menimbulkan rasa cinta untuk membaca.

2. Memperluas dan memperdalam pengiasaan ilmu pengetahuan.

3. Mengembangkan kemampuan belajar. 
4. Membantu mengembangkan kemampuan Bahasa dan dan daya pikir.

5. Pemeliharaan bahan pustaka secara baik.

6. Memberikan kemudahan temu kembali informasi.

7. Menjunjung kegiatan belajar dan mengajar.

8. Tempat rujukan untuk mencari informasi guna pembuatan karya tulis ilmiah maupun penelitian.

Dikarenakan tujuannya memberi layanan informasi literal kepada masyarakat maka tugas pokoknya adalah:

1. Menghimpun bahan pustaka yang meliputi buku dan non buku sebagai sumber informasi;

2. Mengolah dan merawat pustaka; dan

3. Memberikan layanan bahan pustaka.

Klasifikasi pembagian perpustakaan sesuai penerapan teknologi yang digunakan menjadi:

1. Perpustakaan tradisional, yaitu perpustakaan yang sudah sering kita lihat dengan berbagai rak koleksi buku serta pencatatan manual oleh petugas pustakawan.

2. Perpustakaan terotomati, yaitu perputakaan dalam pengelolaanya (pencatatan, perekapan, dan pencetakan) sudah menggunakan teknologi komputer.

3. Perpustakaan digital, yaitu perpustakaan dengan sistem informasi manajemen menggunakan teknologi informasi ditambah koleksi-koleksi digital baik berupa jurnal, ebook, CD audio, maupun koleksi video.

\section{Museum}

\section{1) Pengertian dan Klasifikasi Museum}

Museum berdasarkan definisi yang diberikan International Council of Museums, adalah institusi permanen, nirlaba, melayani kebutuhan publik, dengan sifat terbuka, dengan cara melakukan usaha pengoleksian, mengkonservasi, meriset, mengkomunikasikan, dan memamerkan benda nyata kepada masyarakat untuk kebutuhan studi, pendidikan, dan kesenangan. Karena itu ia bisa menjadi bahan studi oleh kalangan akademis, dokumentasi kekhasan masyarakat tertentu, ataupun dokumentasi dan pemikiran imajinatif di masa depan. Museum 
merupakan suatu badan yang mempunyai tugas dan kegiatan untuk memamerkan dan menerbitkan hasil-hasil penelitian dan pengetahuan tentang benda-benda yang penting bagi Kebudayaan dan llmu Pengetahuan. Menurut Jayanti dan Elisa (2012), museum merupakan gedung yang digunakan sebagai tempat untuk pameran tetap benda-benda yang patut mendapatkan perhatian umum, seperti peninggalan sejarah, seni, dan ilmu.

Museum dapat diklasifikasikan dalam enam kategori, yaitu :

a. Art Museum (Museum Seni)

b. Archeologi and History Museum (Museum Sejarah dan Arkeologi)

c. Ethnographical Museum (Museum Nasional)

d. Natural History Museum (Museum Ilmu Alam)

e. Science and Technology Museum (Museum IPTEK)

f. Specialized Museum (Museum Khusus)

Menurut penyelenggaraannya, museum dapat dibagi menjadi dua, yaitu :

a. Museum Pemerintah, yaitu museum yang diselenggarakan dan dikelola oleh pemerintah baik pemerintah pusat atau pemerintah daerah.

b. Museum Swasta, yaitu museum yang didirikan dan diselenggarakan oleh perseorangan.

Berdasarkan tingkatan koleksinya, museum dapat dibagi 3, yaitu :

a. Museum Nasional, yaitu museum yang memiliki benda koleksi dalam taraf nasional atau dari berbagai daerah di Indonesia.

b. Museum Regional, yaitu museum yang benda koleksinya terbatas dalam lingkup daerah regional.

c. Museum Lokal, yaitu museum yang benda koleksinya hanya terbatas pada hasil budaya daerah tersebut.

2) Tugas dan Fungsi Museum

Tugas Museum:

a. Diarahkan kepada kegiatan untuk menetapkan agar melalui benda, dokumentasi visual dan bahan-bahan pendukung tambahan lainnya, aspek-aspek kebutuhan, aspek-aspek lingkungan hidup/kombinasi diantara keduanya, yang menjadi bidang garapan museum tersebut, menjadi sumber informasi yang mantap.

b. Kegiatan yang berkaitan dengan penyerahan/penyampaian sumber-sumber 
informasi yang sudah mantap itu kepada pengunjung.

Fungsi Museum:

a. Tempat pengumpulan dan pengaman warisan budaya dan alam.

b. Tempat dokumentasi dan penelitian ilmiah.

c. Konservasi dan preservasi.

d. Media penyebaran dan penyerataan ilmu untuk umum.

e. Tempat pengenalan dan penghayatan kesenian.

f. Visualisasi warisan budaya dan alam.

g. Media perkenalan budaya antar daerah dan antar bangsa.

h. Cermin pertumbuhan peradaban umat manusia.

i. Pembangkit rasa bertaqwa dan bersyukur kepada Tuhan YME.

\section{a. Pelestarian dan Kebudayaan}

1) Pelestarian

Menurut Gusmanda dan Nelisa (2013), pelestarian berasal dari kata 'lestari' yang dapat diartikan selamat panjang umur, tetap permanen, abadi dan terus berguna bagi kehidupan umat manusia. Pelestarian merupakan kegiatan atau upaya yang dilakukan untuk mencegah terjadinya kerusakan, agar bisa panjang umur dan terus digunakan untuk suatu keperluan. Pelestarian dilakukan tidak hanya semata mencegah dari kerusakan, tetapi untuk mempertahankan nilai guna dari barang yang bersifat penting untuk jangka waktu yang panjang.

2) Tujuan dan Fungsi Pelestarian

Fungsi pelestarian menurut Martoadmodjo (1994:6) adalah menjaga agar koleksi perpustakaan tidak diganggu oleh tangan jahil, serangga, jamur yang merajalela pada buku-buku yang ditempatkan ditempat yang lembab. Tujuan pelestarian ialah untuk menyelamatkan isi dokumen. Upaya pelestarian ini dilakukan sejak dini sehingga tidak sampai rusak keadaannya

3) Kegiatan Pelestarian

Terdapat beberapa tindakan preventif untuk mencegah sebelum bahan atau koleksi perpustakaan termasuk segala fasilitas, perabotan, dan perlengkapannya mengalami kerusakan, antara lain:

a. Membersihkan secara rutin seluruh pengobatan dan perlengkapan perpustakaan, 
termasuk keadaan ruangan yang harus selalu dalam keadaan bersih.

b. Membungkus atau memberi sampul setiap buku yang dimiliki oleh perpustakaan.

c. Mengatur ventilasi udara supaya tetap dalam keadaan normal, tidak terlalu dingin dan tidak terlalu panas. Sinar matahari diusahakan supaya tidak langsung menembus ruangan perpustakaan.

d. Membersihkan koleksi buku dan lainnya dengan menggunakan pembersih (sunda=maceng) atau dengan kuas berbulu halus dan lap yang bersih.

e. Memberi peringatan kepada para pengguna agar secara bersama-bersama turut menjaga kebersihan dan kelestarian perpustakaan.

f. Memasang rambu-rambu peringatan di ruang perpustakaan yang isinya memohon kepada pengunjung agar menjaga kebersihan dan keamanan.

g. Menjaga kerapihan letak buku-buku atau koleksi perpustakaan, termasuk perlengkapan dan perabotnya agar selalu dalam keadaan siaga layanan.

4) Kebudayaan

Menurut Supriyanto dan Muhsin (2012), budaya di dalam sansekerta buddhi (buddhayah adalah bentuk jamaknya, dan dengan demikian "Kebudayaan” Dapat diartikan "Pikiran dan akal" Kebudayaan merupakan keseluruhan yang kompleks, yang di dalamnya terkandung pengetahuan, kepercayaan, kesenian, moral, hukum, adat istiadat, serta kemampuan-kemampuan lain yang di dapat seseorang sebagai anggota masyarakat.

Budaya juga diartikan sebagai cara atau sikap hidup manusia dalam hubungannya secara timbal balik dengan alam dan lingkungan hidupnya yang di dalamnya sudah tercakup pula segala hasil dari cipta, rasa, karsa, dan karya, baik yang fisik materil maupun yang psikologis, idil dan spiritual. Dengan kata lain kebudayaan mencakup semua yang didapatkan atau dipelajari oleh manusia sebagai anggota masyarakat. Kebudayaan terdiri atas segala sesuatu yang dipelajari dari pola-pola perilaku yang normatif, artinya mencakup segala cara-cara atau pola-pola berpikir, merasakan dan bertindak.

\section{b. Peranan Perpustakaan dalam Pelestarian Budaya}

Bangsa Indonesia mempunyai sosial budaya yang beragam banyaknya. 
keanekaragaman seni dan budaya inilah yang membuat Indonesia menjadi salah satu negara yang cukup diperhitungkan dimata dunia. Kebudayaan merupakan aset sejarah berharga sebuah bangsa yang harus dijaga, dan diwariskan secara turun temurun. Pelestarian warisan budaya bangsa merupakan hal yang berkelanjutan dalam menjaga kumpulan karya-karya anak bangsa dan budaya bangsa untuk tetap terjaga serta bermanfaat bagi masyarakat masa kini dan masa yang akan datang.

Perpustakaan berperan sebagai wahana pelestari sikap budaya manusia dari masa ke masa. Perpustakaan bertugas menyimpan khasanah budaya bangsa serta tempat untuk mendidik dan mengembangkan apresiasi budaya masyarakat. Dalam Undang-undang Nomor 43 Tahun 2007 tentang perpustakaan yang menyatakan bahwa pemerintah provinsi dan kabupaten/kota berkewajiban untuk menyelenggarakan dan mengembangkan perpustakaan umum daerah berdasar kekhasan daerah masing-masing dan keberadaan perpustakaan tidak dapat dipisahkan dari peradaban dan budaya umat manusia. Perpustakaan sebagai sistem pengelolaan rekaman gagasan, pemikiran, pengalaman dan pengetahuan manusia, mempunyai fungsi utama melestarikan hasil budaya umat manusia tersebut, khususnya yang berbentuk dokumen karya cetak dan karya rekam.

Berdasarkan uraian di atas maka dapat dinyatakan bahwa perpustakaan selain berperan sebagai wahana pelestari berbagai jenis khazanah budaya bangsa, juga berperan membina dan menumbuhkan kecintaan masyarakat terhadap budaya daerah masing-masing dan karya anak bangsa yang ada di Indonesia serta dapat mewariskan kebudayaan tersebut kepada setiap generasi dalam berbagai media.

\section{c. Tembakau di Kota Jember}

Di mata para juragan hecho en Cuba alias cerutu Kuba, Indonesia ibarat la tierra prometadora, sebuah tanah yang menjanjikan. Kuba maupun negara-negara penghasil cerutu terbaik sedunia tak pernah lupa menoleh ke Indonesia pada saat mereka membutuhkan bahan baku cerutu.

Dunia internasional juga mengenal Besuki Na Oogst (BNO), daun tembakau yang dihasilkan dari Besuki, Jember, yang cocok dipakai sebagai pembalut, pengikat atau pembungkus, bahkan pengisi cerutu. Tembakau Besuki, yang 
mengharumkan nama Jawa Timur, unggul dalam karakter elastisitas, rasa, serta warna daun yang cokelat kehitaman. Tradisi cerutu Indonesia berasal dari Belanda. Tak jelas, apa dan siapa pabrik cerutu pertama di Hindia Belanda. Namun, yang tertua dan masih bertahan sampai sekarang adalah Industri Bobbin PTPN X di Desa Jelbuk, Jember. Usia tembakau di tempat tersebut selama 2 abad lebih.

Sejak dulu, Jember terkenal dengan tembakaunya. Tembakau Jember diekspor ke Bremen, Jerman. Tembakau Jember dimanfaatkan terutama untuk bahan pembalut cerutu (dekblad) selain sebagai bahan pengikat (binder) serta pengisi (filler) aroma cerutu yang berkualitas tersebut. Tembakau dari Jember itu tidak kalah dengan cerutu Kuba maupun Amerika. Lebih dari dua abad lamanya tembakau ini ada dan tumbuh di daerah Jember. Mulanya, adalah George Bernie yang mendapatkan hak erfpacht atau hak guna usaha untuk jangka waktu 75 tahun di daerah Jember di Jenggawah. Ia menggarap areal perkebunan ini untuk usaha perkebunan tembakau jenis BNO (Besuki Na Oogst).

Zaman pun berganti perkebunan tersebut lalu dikelola oleh badan hukum milik Pemerintah Hindia Belanda. Setelah pendudukan Jepang, perusahaan ini kemudian dinasionalisasikan. Lahan perkebunan itu sempat timbul konflik antara petani dengan PT Perkebunan (PTP) XXVII. Konflik ini bisa diselesaikan. Petani memperoleh hak milik atas lahan tersebut. PTP XXVII, XIX, XXI, dan XXII pada tahun 1996 kemudian melebur menjadi PT Perkebunan Nusantara X. Masyarakat setempat biasa menanam tembakau. Sampai-sampai tanaman tembakau menjadi trade mark Kabupaten Jember. Tidak mengherankan bila pemerintah kabupaten memakai daun tembakau sebagai salah satu gambar yang menghias lambang daerahnya (Fahreza, 2012).

\section{PEMBAHASAN}

\section{Gambaran Perlunya Pelestarian Budaya Tembakau}

Jawa Timur merupakan salah satu daerah penghasil tembakau utama di Indonesia. Setiap tahunnya Jawa Timur memberikan kontribusi produksi tembakau sebesar 83.404 ton atau sekitar 50-55\% dari kebutuhan nasional. Sedangkan budidaya tembakau di Jawa Timur tersebar di 20 kabupaten dengan 
luasan rata-rata 110.791 ha yang terdiri dari tembakau voor-Oogst seluas 103.878 ha dan Na-Oogst sebesar 6.913 ha. Sebagai salah satu kabupaten yang terletak di Jawa Timur, Jember termasuk ke dalam kota penghasil tembakau Jawa Timur. Perkebunan tembakau di Jember tersebar di beberapa kecamatan. Sebagian besar perkebunan tersebut berada di bawah naungan dan pengawasan PT. Perkebunan Nusantara X Jember. Perusahaan ini merupakan perusahaan yang bergerak di bidang pertanian. Salah satu budidayanya adalah tanaman tembakau.

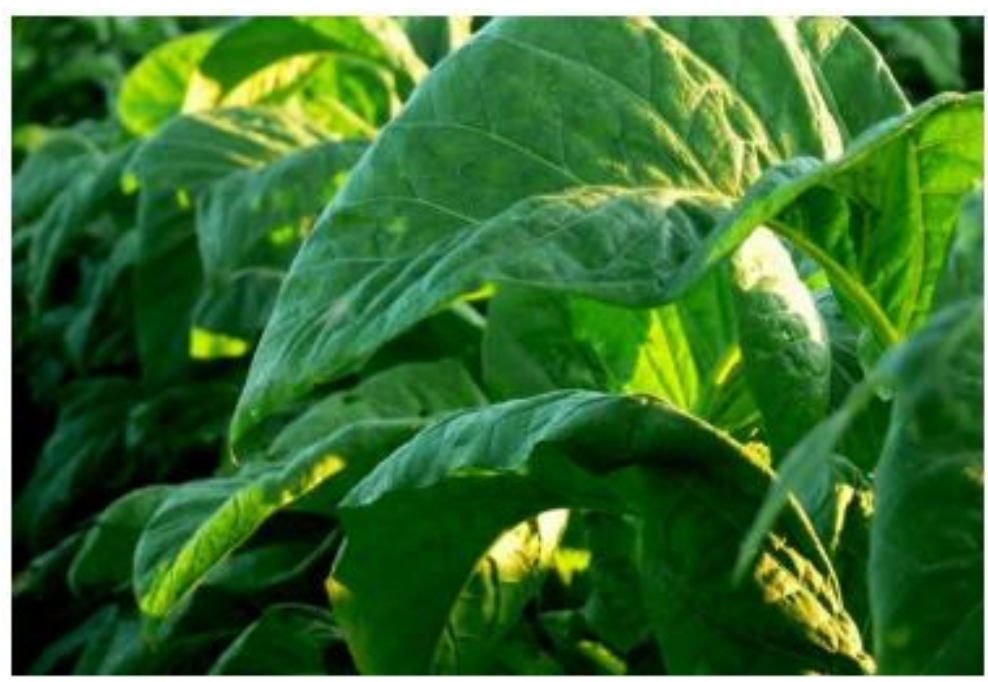

Gambar 1. Tanaman Tembakau

Berdasarkan informasi yang dikemukakan oleh pihak PT. Perkebunan Nusantara X Jember, lahan yang diperlukan oleh PT. Perkebunan Nusantara X Jember untuk penanaman tembakau sangat banyak, sementara lahan yang dimiliki terbatas. Hal ini bertujuan untuk menjaga kualitas tembakau. Alasannya adalah penggunaan lahan untuk tanaman tembakau tidak boleh dilakukan terus menerus. Setelah penanaman tembakau, suatu lahan harus ditanami tanaman lain yang tidak se-family dengan tembakau. Jadi, dilakukannya pelestarian budaya tembakau sendiri Karena ketersediaan SDA dan SDM yang memadai sehingga sangat disayangkan apabila prospek tersebut tidak dimanfaatkan (Nandadiri, 2014). Selain itu, betapa pentingnya tembakau bagi masyarakat Jember bahkan tembakau sudah menjadi bagian atau ciri khas Jember maka perlunya pelestarian agar keberadaannya tetap terjaga.

1. Pentingnya Keberadaan Tembakau bagi Masyarakat 


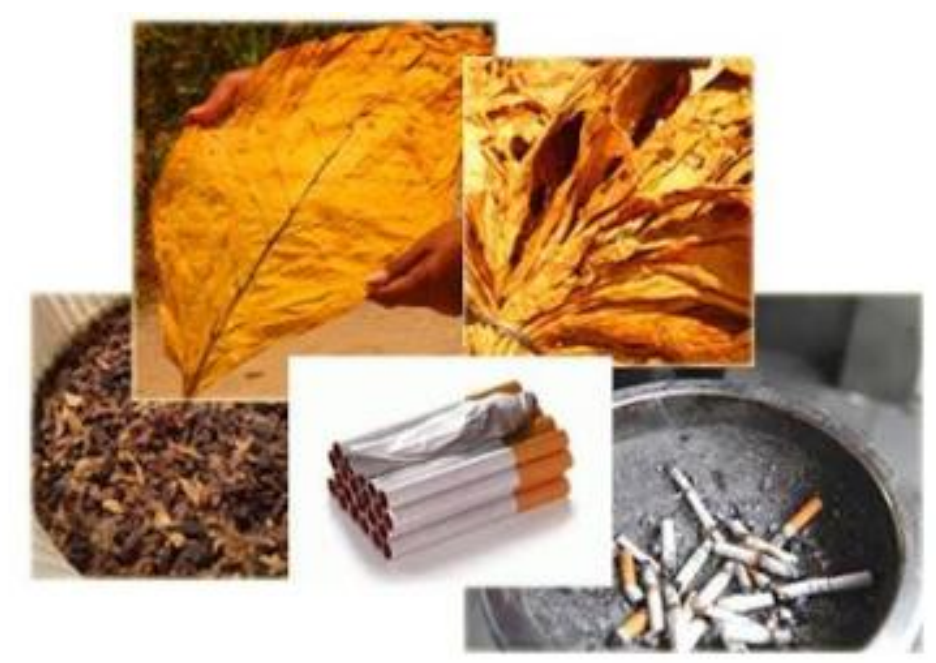

Gambar 2. Produk Hasil Olahan Tembakau

Keberadaan tanaman tembakau sendiri telah menjadi ciri khas terutama masyarakat kota Jember . Tanaman tembakau juga sebagai ikon Kota Jember. Jadi sangat penting bagi masyarakat jember dan sebagai pengetahuan serta kebudayaan yang sangat melekat dari generasi ke generasi. Namun, dari beberapa pernyataan tersebut didapat sisi positif dan negatif bagi masyarakat, antara lain:

1. Kegiatan budidaya tembakau dapat menambah penghasilan masyarakat Kota Jember.

2. Nilai investasi dapat di tingkatkan dengan keberadaan tembakau

3. Menambah variasi penanaman jenis tanaman di Kota Jember

4. Dengan adanya tembakau dan perpustakaan jember menambah obyek wisata terutama bidang pendidikan di Kota Jember

5. Tingkat konsumsi rokok di masyarakat semakin berkembang pesat.

6. Kemungkinan dapat terjadi alih komoditas penanaman ke tembakau apabila omset produksinya mengalami peningkatan.

\section{Peran Perpustakaan dan Museum Tembakau}

a. Peran Perpustakaan dan Museum Tembakau

Tanaman tembakau merupakan tanaman yang ditanam secara turun temurun oleh sebagian warga di Kabupaten Jember, Jawa Timur. Bahkan, para petani tradisional di kabupaten setempat tetap menanam tembakau, meskipun harus menderita kerugian akibat harga tembakau yang anjlok. Warisan pertanian tembakau yang turun temurun di Jember tersebut menyebabkan kabupaten 
setempat dikenal sebagai "Kota Tembakau" karena hasil tembakaunya yang mendunia dan berkualitas. Jadi, tidak heran kalau Jember memiliki museum dan perpustakaan tembakau yang dikelola oleh Unit Pelaksana Teknis (UPT) Pengujian Sertifikasi Mutu Barang - Lembaga Tembakau Jember Dinas Perindustrian dan Perdagangan Provinsi Jawa Timur yang berada di Jalan Kalimantan Nomor 1 Jember.

Peran Perpustakaan dan Museum Tembakau yaitu untuk melestarikan sekaligus mengenalkan tembakau serta memberikan pengetahuan tentang tembakau kepada masyarakat. Di perpustakaan dan museum tembakau tersebut, masyarakat bisa mendapat ilmu pengetahuan tentang tanaman tembakau, Seperti buku dan video dukumenter tentang sejarah tembakau di Jember, serta berbagai pengetahuan tentang manfaat tembakau selain untuk rokok. Para pengunjung juga bisa melihat film dokumenter sejarah masyarakat yang sejak jaman Belanda sudah bertanam tembakau. Serta dipamerkan juga bermacam macam alat kuno yang digunakan masyarakat Jember, seperti alat lintingan rokok, dan kota penyimpanan tembakau. Nuansa museum yang modern dan minimalis tersebut berbeda dengan museum pada umumnya yang biasanya dipenuhi dengan barang-barang kuno dan terkesan kaku karena di museum tembakau tersebut banyak dipajang berbagai daun tembakau dari sejumlah daerah dan produk diversifikasi tembakau.

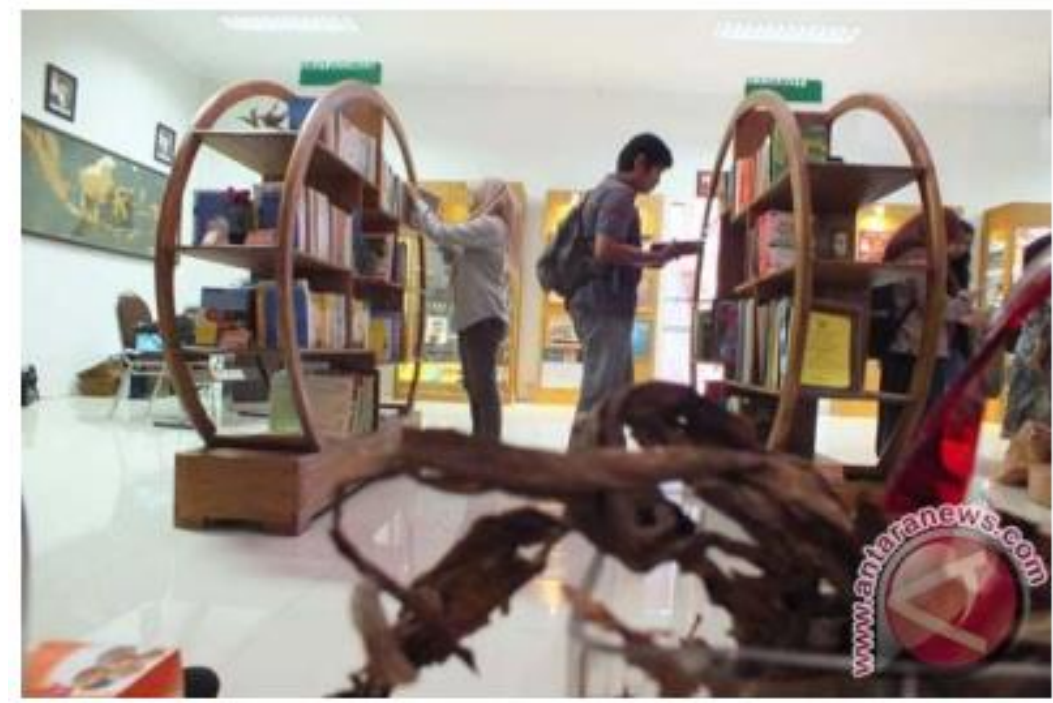

Gambar 3. Perpustakaan dan Museum Tembakau 
Memasuki pintu museum, pengunjung langsung disambut nuansa tembakau dengan aksesoris gedung seperti lukisan petani di hamparan hijaunya tembakau, lukisan tarian khas Jember tentang tembakau (Labako), dan juga lukisan seorang lelaki tua yang menghisap cerutu. Di museum juga tersedia lembaran daun tembakau kering yang berasal dari sejumlah perusahaan penjual dan pengekspor tembakau di Jember seperti PTPN X, Kopa TTN, PT Mayangsari, PT GMIT, PT Tempurejo dan PT IDS, dan PT ITT. Perusahaan tembakau tersebut merupakan sedikit dari puluhan perusahaan pembeli tembakau rakyat Jember dan mereka yang menjual tembakau Jember keluar daerah seperti luar Jawa, bahkan luar negeri seperti ke Eropa karena tembakau Jember sangat terkenal.

Aneka daun tembakau rajang dari sejumlah kota sentra tembakau di Indonesia juga ada seperti tembakau rajang Maesan (Bondowoso), Prancak (Sumenep), Tanjungsari Tasikmalaya (Jawa Barat), Paiton - Besuk (Probolinggo), Curahnongko tanpa gula (Jember), tembakau Bojonegoro dan Sinjai. Selain tembakau yang dipamerkan dalam museum itu, diversifikasi produk tembakau pun menghiasi ruangan tersebut seperti parfum, bio diesel, pestisida tanaman, pupuk organik, dan minyak atisiri, filter rokok, dan produk pengobatan.

\section{b. Kendala Pelestarian Budaya Tembakau}

Jember dulu sangat dikenal oleh dunia internasional khususnya Eropa karena tembakaunya, namun saat ini perlahan-lahan ingatan tersebut mulai luntur dan kurangnya kesadaran masyarakat tergerus oleh perkembangan zaman yang modern sehingga membuat kendala dalam pelestarian budaya tembakau agar tetap terjaga keaslian dan ciri khasnya. Potensi tembakau di Jember seharusnya bisa menjadi paket wisata yang menarik. Museum itu rencananya akan dilengkapi miniatur gudang atak, gudang pengeringan tembakau, dan juga cangkul milik George Birnie, warga negara Belanda keturunan Skotlandia yang membuka perusahaan perkebunan tembakau pertama di Jember tahun 1850.

\section{c. Prospek Pengembangan Perpustakaan dan Museum Tembakau}

Menurut Solicha (2015), potensi wisata tembakau bisa dikembangkan menjadi salah satu destinasi wisata di Jember karena banyak perusahaan dan 
sentra tembakau yang bisa dikemas menjadi paket wisata unik untuk para wisatawan mancanegara. Selain itu, di museum tersebut pengunjung juga bisa melihat SNI Corner yakni merupakan inovasi baru dari Badan Standarisasi Nasional (BSN) untuk meningkatkan persepsi masyarakat dengan menghadirkan perpustakaan mini yang berisi tentang informasi SNI.

UPT Pengujian Sertifikasi Mutu Barang dan Lembaga Tembakau Jember merupakan mitra BSN dalam penilaian kesesuaian khususnya untuk standar tembakau yang aktif melakukan kerja sama dalam kegiatan penerapan SNI sebagai kepanjangan tangan BSN dalam menerapkan standardisasi di Jember. SNI Corner di Lembaga Tembakau Jember itu merupakan ketiga di Indonesia setelah sebelumnya ada di IPB dan ITS, serta merupakan yang pertama di luar lingkungan universitas. Pihak penyelenggara berharap ke depan nantinya, koleksi tanaman tembakau di daerah lain di Indonesia bisa ditampilkan di museum tembakau yang di kelolanya karena rajangan tembakau di tiap-tiap daerah berbeda. Seperti rajangan tembakau Sinjai, selain halus juga dibentuk bulat seperti makanan rolade. Sedangkan rajangan tembakau Tanjungsari Tasikmalaya lebih tipis dan lembut dibandingkan rajangan Maesan atau Bojonegoro. Bahkan, tiap tembakau juga memiliki warna yang berbeda. Selain itu kedepannya, UPT Pengujian Sertifikasi Mutu Barang dan Lembaga Tembakau Jember akan bekerjasama dengan Dinas Pariwisata dan Kebudayaan Jember untuk pengembangan perpustakaan dan museum tembakau tersebut. Agar para pengunjung akan diajak berkeliling langsung ke petani tembakau, kebun serta lumbung tembakau.

\section{PENUTUP}

\section{Kesimpulan}

Berdasarkan pembahasan diatas diperoleh beberapa kesimpulan, antara lain:

1. Pelestarian budaya tembakau perlu dilakukan guna mengoptimalkan ketersediaan SDA dan SDM di Kota Jember serta pentingnya tembakau bagi masyarakat Jember bahkan tembakau sudah menjadi bagian atau ciri khas Jember maka perlunya pelestarian agar keberadaannya tetap terjaga.

2. Keberadaan tanaman tembakau sendiri telah menjadi ciri khas terutama masyarakat kota Jember. Tanaman tembakau juga sebagai ikon Kota Jember. Jadi 
sangat penting bagi masyarakat jember dan sebagai pengetahuan serta kebudayaan yang sangat melekat dari generasi ke generasi.

3. Perpustakaan memiliki peran dan fungsi dalam pelestarian kebudayaan. Salah satunya Perpustakaan dan Museum Tembakau Kota Jember. Peran Perpustakaan dan Museum Tembakau sendiri adalah mengoptimalkan dan sebagai wadah untuk kelestarian budaya tembakau sehingga tetap terjaga keberadaannya.

4. Pengembangan Perpustakaan dan Museum Tembakau kedepannya, diharapkan koleksi tanaman tembakau di daerah lain di Indonesia bisa ditampilkan di Perpustakaan dan Museum Tembakau dan nantinya dapat bekerjasama dengan Dinas Pariwisata dan Kebudayaan Jember dalam pengembangannya.

\section{Saran}

1. Pelaksanaan budidaya tembakau pada dasarnya harus tetap pada ambang batasnya supaya sisi positif dan negatif bagi masyarakat tetap terkontrol.

2. Adanya kesadaran dari seluruh masyarakat khususnya masyarakat Kota Jember dalam melestarikan tembakau dan ikut berpartisipasi dalam menjaga dan mengembangkan perpustakaan dan museum tembakau untuk kelestarian budaya tembakau dan pengetahuan bagi masyarakat.

\section{DAFTAR PUSTAKA}

Fahreza, Muhammad dan Ilham. 2012. Sejarah Tembakau di Kota Jember. http://www.kaskus.co.id/thread/52f069c5a1cb17704b8b470d/kenali-negeri mu-kota tembakau-jember-jawa-timur/ . Diakses pada 22 Oktober 2016.

Gusmanda, R dan M. Nelisa. 2013. Pelestarian Naskah-Naskah Kuno di Museum Nagari Adityawarman Sumatera Barat. Jurnal Ilmu Informasi Perpustakaan dan Kearsipan, 2 (1) : 573-581.

Jayanti, S dan M. Nelisa. 2012. Perancangan Web Sebagai Media Promosi Koleksi Naskah Kuno Minangkabau di Museum Adityawarman Sumatera Barat. Jurnal Ilmu Informasi Perpustakaan dan Kearsipan, 1 (1) : 295-304.

Nandadiri, Annisa, D. I. Swasono dan N. O. Adiwijaya. 2014. Sistem Informasi Geografis Pemilihan Lahan Tembakau di Kabupaten Jember Berbasis Web Menggunakan Metode Topsis-AHP. Jurnal Ilmiah Hasil Penelitian 
Mahasiwa, 1 (1) : 1-8.

Solicha Zumrotun. 2015. Melongok Museum Tembakau di Jember. http://www.antarajatim.com/lihat/berita/157901/melongok-museum-temba kau-di-jember. Diakses pada 22 Oktober 2016.

Supriyanto, W dan A. Muhsin. 2012. Teknologi Informasi Perpustakaan: Strategi Perancangan Perpustakaan Digital. Yogyakarta : Kanisius.

Sulistyo-Basuki. 1991. Pengantar Ilmu Perpustakaan. Jakarta: Gramedia Pustaka Utama. 